Rio de Janeiro. Ano 15. Volume 22. Número 3. Setembro a Dezembro de 2021

Periódico Quadrimestral da Pós-Graduação Stricto Sensu em Direito Processual da UERJ

Patrono: José Carlos Barbosa Moreira (in mem.). ISSN 1982-7636. pp. 288-314

www.redp.uerj.br

\title{
RECONFIGURAÇÃO DO RECURSO ESPECIAL: UMA MUDANÇA IMPRESCINDÍVEL E INADIÁVEL
}

\section{RECONFIGURATION OF THE SPECIAL APPEAL: A NECESSARY AND INADIABLE CHANGE}

Fabio Resende Leal

Doutor e mestre em Direito (Centro Universitário de Bauru CEUB/Instituição Toledo de Ensino - ITE). Especialista em Direito Empresarial (CEUB/ITE). Professor Titular da Universidade Paulista - UNIP. Advogado. Bauru/SP. E-mail: fabio@lla.adv.br

RESUMO: Este artigo analisa dados estatísticos do Superior Tribunal de Justiça e o conteúdo do artigo 105, inciso III, da Constituição. O primeiro objetivo é comprovar o acerto da afirmação segundo a qual o STJ padece dos males incuráveis decorrentes de um gigantesco acervo processual. O segundo objetivo é demonstrar que as atuais regras de admissibilidade do recurso especial contribuem para o crescimento desse acervo. Por derradeiro, o terceiro e principal objetivo é propor, como conclusão, alterações textuais a serem feitas na Constituição, para otimizar e objetivar a jurisdição que o STJ pratica ao conhecer e julgar dos recursos especiais.

PALAVRAS-CHAVE: Superior Tribunal de Justiça; recurso especial; admissibilidade; relevância da questão federal; objetivação.

ABSTRACT: This article analyzes statistical data of the Superior Court of Justice and the content of article 105, subsection III, of the Constitution. The first objective is to prove the correctness of the statement that the STJ suffers from incurable evils, resulting from a gigantic procedural collection. The second objective is to demonstrate that the current rules for the admissibility of the special appeal contribute to the growth of this collection. Finally, the third and main objective is to propose, as a conclusion, textual changes to be made in the 
Constitution, to optimize and objectify the jurisdiction that the STJ practices when knowing and judging special appeals.

KEYWORDS: Superior Court of Justice; special appeal; admissibility; relevance of federal question; objectification.

\section{Introdução}

Este artigo, que tem como foco de análise os enormes números do Superior Tribunal de Justiça e suas dificuldades em lidar com o sistema recursal criado pela Constituição Federal, é estruturado como um silogismo: a partir da conjugação de duas premissas se chega a uma conclusão, por força da qual, posteriormente, serão sugeridas alterações a serem feitas no texto constitucional.

A primeira premissa, ou constatação fática, se relaciona com o gigantismo dos dados estatísticos apresentados pelo STJ. A Corte, tal como desenhada em 1988, se vê às voltas com um acervo processual que, a despeito dos esforços empreendidos nos últimos anos e do crescimento quantitativo na produção dos ministros, ainda está muito longe de ser vencido ou do número que seria adequado a um tribunal pensado e vocacionado não para julgar casos concretos, mas, sim, para estabelecer teses jurídicas abstratas e vinculantes.

A segunda constatação é a de que o artigo 105, inciso III, da Carta Magna, de textura normativa ampla e quase que irrestrita, acaba por estimular ou, quando menos, permitir que uma grande gama de processos cujos temas não têm relevância nem transcendência cheguem aos gabinetes do STJ, perpetuando, por conseguinte, o desfecho de casos que só interessam às partes e, ao mesmo tempo, sobrecarregando sobremaneira o Tribunal.

Assim sendo, é imprescindível e inadiável reformarmos nosso sistema de justiça, para limitar ainda mais o acesso, objetivar a jurisdição que se pratica no STJ e, consequentemente, otimizar a atuação deste sodalício. Só que para isso acontecer de maneira adequada se faz necessário alterar textualmente a Constituição. É preciso haver, em seu artigo 105, inciso III, a ressalva textual de que o recurso especial, antes de servir à revisitação e solução do conflito intersubjetivo que afasta recorrente de recorrido (função recursal), deve se prestar à definição paradigmática de questão federal relevante e transcendente (função 
nomofilácica). Na sequência, há de se prever um novo requisito de admissibilidade para o apelo extremo, a relevância da questão federal, sem a qual as portas do STJ deverão permanecer fechadas a recorrente e recorrido. Por fim, é preciso existir autorização constitucional para que as teses jurídicas fixadas em recurso especial, mesmo se não afetado para julgamento pela técnica dos repetitivos, tenham efetivo vinculante, de modo a servir de paradigma decisório obrigatório às causas análogas, sob pena de reclamação.

\section{Primeira constatação}

Tem-se por certo, nos meios acadêmico e forense, que o Superior Tribunal de Justiça se vê preso a um colossal acervo processual, o qual, apesar do hercúleo trabalho executado, não dá mostras de estar substancialmente diminuindo ano a ano. Rápida análise dos relatórios estatísticos que a Corte disponibiliza desde 2002 permite visualizar o tão propalado crescimento, forte e constante, dos números de processos admitidos e julgados. A fim de detalhar esses números, me vali dos dados estatísticos de 2017, 2018 e 2019 que a Assessoria de Modernização e Gestão Estratégica e a Coordenadoria de Gestão de Informação do STJ disponibilizam no site da Corte. Optei por deixar de fora da análise 2020, ano, como se sabe, deveras atípico, em razão da interrupção dos trabalhos presenciais em decorrência da pandemia de Covid-19.

Em 2017, o STJ recebeu 332.284 novos processos, incluindo ações de competência originária e recursos, dentro da média histórica de $330 \mathrm{mil}$ processos/ano verificada nos cinco anos anteriores. Desses novos processos, a maioria veio de São Paulo (30,5\%). Os três maiores demandantes foram o INSS (140.470 processos), a Fazenda Nacional (93.916 processos) e a União (72.064 processos). Os temas mais versados foram contratos bancários (73.511 processos), dívida ativa (65.186 processos) e tráfico de drogas (60.841).

A produtividade em 2017 foi imensa, como nos anos anteriores. Foram proferidas, ao todo, 490.473 decisões, das quais 97.510 se deram em recursos internos (agravos internos, agravos regimentais, embargos de declaração e embargos de divergência). Julgou-se, em média, 40.873 processos por mês, sendo 8.126 recursos internos.

Apenas em 2017, foram protocolados 107.612 recursos internos, com média mensal de 8.968 protocolos e 272 distribuições para cada ministro. Apesar disso, considerando a 
média histórica, a taxa de recorribilidade interna sofreu uma redução de 21,9\%. Foram “baixados” 373.931 processos (média mensal de 31.161 processos ou 1.416 por dia útil).

Aquele ano terminou com um acervo de 332.330 processos, uma redução de 11,3\% (42.402 processos) em relação a 2016. Quase $80 \%$ do acervo era composto de agravos em recurso especial (42,8\%) e recursos especiais (36,5\%). A Corte julgou, em 2017, 204.014 AREsp e 101.123 REsp. ${ }^{1}$

Os números do ano seguinte foram parecidos. Foram recebidos 346.337 novos processos (28.861 processos por mês ou 1.467 por dia útil). De novo, os maiores litigantes foram o INSS (139.139 processos), a Fazenda Nacional (94.400 processos) e a União (70.144 processos), assim como os temas mais discutidos foram contratos bancários (60.841 processos), dívida ativa (63.445 processos) e tráfico de drogas (80.506). Houve considerável incremento no número de recursos internos (aumento de 23,3\%), provavelmente causado pelas novas regras trazidas pelo Código de Processo Civil de 2015, especialmente no tocante à necessidade de fundamentação mais completa e proibição de reprodução dos argumentos anteriores.

Julgou-se, em 2018, mais de meio milhão de processos: foram 524.801 as decisões prolatadas naquele ano. Sozinho, Gurgel de Faria, o ministro de maior produtividade em termos estatísticos, proferiu 23.021 decisões. Supondo ter havido trabalho ininterrupto ao longo do ano, chegamos a estratosféricas 63,07 decisões por dia ou 2,62 decisões por hora só do Ministro Gurgel de Faria.

Com o intenso trabalho realizado, a redução do acervo foi maior do que a verificada no ano antecedente, chegando a 383.706 processos baixados. O ano de 2018 terminou com “apenas” 292.757 processos em tramitação (redução de 11,9\%).

Em 2018, o STJ recebeu 189.734 agravos em recurso especial e 69.547 recursos especiais, tendo julgado 214.331 AREsp e 100.665 REsp. Do acervo remanescente, os agravos em recurso especial somavam $42,7 \%$ e os recursos especiais, $35,6 \%{ }^{2}$

\footnotetext{
1 Superior Tribunal de Justiça. Relatório Estatístico 2017. Disponível em: http://www.stj.jus.br/webstj/Processo/Boletim/verpagina.asp?vPag=0\&vSeq=301. Acesso em: 8 nov. 2018.

2 Superior Tribunal de Justiça. Estatístico 2018.2 Disponível em: http://www.stj.jus.br/webstj/Processo/Boletim/verpagina.asp?vPag=0\&vSeq=327. Acesso em: 29 abr. 2019.
} 
Finamente, 2019 caracterizou-se pelo considerável salto na quantidade de processos recebidos. Os 384.900 novos processos que aportaram no STJ representaram um acréscimo de 11,1\% (38.581) em relação ao ano anterior. Para se der uma ideia do crescimento, em 2013, foram recebidos "somente" 299.310 novos processos. Em 1989, ano de instalação da Corte, foram distribuídos 6.103 processos, enquanto em 1999 e 2009, se distribuíram, respectivamente, 118.977 e 292.103 processos.

Do total de recebidos em 2019, 241.778 (62,8\%) vieram dos Tribunais de Justiça, sendo 98.141 (25,5\%) só do TJSP; 54.757 (14,2\% = acréscimo de 17,8\% em relação a 2018), dos Tribunais Federais Regionais; 88.045 (22,8\%), do próprio STJ; e 319 (0,08\%), de outros tribunais. Os agravos em recurso especial totalizaram $214.779(55,8 \%=$ acréscimo de 10,7\% em relação a 2018), e os recursos especiais, 68.183 (17,7\% = acréscimo de 8,5\% em relação a 2018, depois de quatro anos consecutivos de queda).

Os principais demandantes foram o INSS (126.307), a Fazenda Nacional (88.158) e o Ministério Público do Estado de São Paulo (77.205), novidade em relação aos dois anos anteriores. A União contribuiu com 66.470 novos processos e a Defensoria Pública de São Paulo, com 54.109. Chama a atenção o número de processos envolvendo o Banco do Brasil, o quinto maior litigante, figurando em 60.671 feitos, e a Caixa Econômica Federal, o décimo, em 22.870. Podem explicar esse protagonismo, os assuntos mais discutidos em 2019, os quais, repetindo 2017 e 2018, foram, de novo, tráfico de drogas (98.805), dívida ativa (57.869) e contratos bancários (55.037).

Em 2019, foram distribuídos 374.366 processos, dos quais 13.462 (52,6\%) foram destinados aos ministros e 12.150 (47,4\%), à Presidência do STJ ou às Presidências dos órgãos julgadores do Tribunal. Aliás, é importante destacar que, tendo trazido para si a tarefa de fazer a triagem dos novos casos, a Presidência da Corte foi o órgão que mais produziu no ano findo: proferiu 147.114 decisões. Dos ministros, Joel Ilan Paciornik apresentou os maiores números, com 19.094 decisões, das quais 10.215 foram monocráticas e apenas 3.635 colegiadas (as outras decisões foram liminares ou demais formas de interlocutórias). $\mathrm{O}$ Tribunal, como um todo, prolatou 543.381 decisões, aumentando em $8 \%$ sua produtividade em relação a 2018 e mantendo, desde 2013, uma média de crescimento na taxa de produtividade na ordem de $9 \%$ ao ano. 
O Relatório Estatístico de 2019 trouxe, como uma de suas novidades, a discriminação quanto ao resultado dos recursos. As principais classes de feitos julgadas, como nos anos anteriores, foram o AREsp 220.447 (40,5\%) e o REsp 91.617 (16,8\%). Em um universo de 220.447 julgados, apenas $4 \%$ dos agravos em recursos especiais foram concedidos. A Corte negou provimento a 28,9\% AREsp, não conheceu $63 \%$ deles e lhes deu desfecho diverso (homologação de desistência ou acordo, por exemplo) em 4,1\% das vezes. Dos recursos especiais, $31,5 \%$ foram concedidos; $30,9 \%$, negados; $23,1 \%$, não conhecidos e $14,5 \%$ acabaram recebendo outras decisões.

A recorribilidade interna, em 2019, se manteve alta. Foram protocolizados 134.634 recursos internos (AgInt, AgRg, EDcl e EDv), com baixíssima taxa de sucesso. Não encontrei, no relatório, o porcentual de embargos de divergência exitosos, mas foram providos apenas 5,4\% dos agravos internos, 5,8\% dos agravos regimentais e 11,44\% dos embargos de declaração.

Por outro lado, o acervo continuou diminuindo. Ao final de 2019, restavam pendentes de solução 269.218 processos, número $8 \%$ menor do que em 2018. Considerando a série histórica, de 2014 a 2019, o Tribunal manteve a redução de seu acervo na média anual de 8,4\%. Mesmo assim, ainda há muito trabalho represado. Na Primeira Seção, o Ministro Napoleão Nunes Maia Filho (aposentado em 2020) tinha consigo, ao final de 2019, entre gabinete e secretaria, 13.346 processos aguardando definição. Na Segunda Seção, o ministro de maior acervo naquele ano era Raul Araújo, com 10.542 feitos, e, na Terceira, Antonio Saldanha Palheiro, com 8.026. ${ }^{3}$

Esse, como antes dito, é o grande problema. Como constou do Relatório Estatístico de 2019, mesmo que não houvesse o ingresso de novas demandas e fosse mantida a produtividade dos ministros, seriam necessários quase oito meses para "zerar" o estoque de processo. Acrescentando-se na conta os processos recebidos, o prazo seria de mais de doze anos para "zerar" o acervo. ${ }^{4}$

\footnotetext{
3 Superior Tribunal de Justiça. Relatório Estatístico 2019. Disponível em: http://www.stj.jus.br/webstj/Processo/Boletim/verpagina.asp?vPag=0\&vSeq=343. Acesso em: 30 jan. 2020. 4 Superior Tribunal de Justiça. Relatório Estatístico 2019. Disponível em: http://www.stj.jus.br/webstj/Processo/Boletim/verpagina.asp?vPag=0\&vSeq=343. Acesso em: 30 jan. 2020, p. 32.
} 
Como o número de novos casos segue crescendo ano a ano, mesmo se a Corte conseguir aumentar quantitativamente ainda mais a sua produtividade, alcançando, por exemplo, uma média de redução de acervo próxima a $11 \%$ ao ano, ainda seriam necessários mais sete ou oito anos para que a quantidade de processos ficasse próxima de $30.000 \mathrm{ou}$ 1.000 processos por ministro com atribuições judicantes, número que, me parece, considerando a complexidade das disputas travadas no STJ, estaria, aí sim, próximo do que idealmente podemos almejar em um país de litigiosidade extrema como é o Brasil.

Assim, à vista desses números, constata-se, até com relativa facilidade, que o sistema, tal como hoje estruturado, está perto de inviabilizar-se em razão da quantidade de ações, recursos e incidentes que abundam nos gabinetes e secretarias do STJ. É preciso, pois, diminuir, e bastante, o acervo processual do Tribunal.

\section{Segunda constatação}

Verificado o gigantismo dos números que assolam o Superior Tribunal de Justiça, é preciso tentar entender suas origens. Por que são tantos os recursos a chegar a uma corte que deveria se preocupar muito mais com a definição de teses em abstrato (função nomofilácica) do que com o julgamento de casos concretos (função recursal)?

O problema é histórico entre nós. Desde os seus primórdios, o Supremo Tribunal Federal sofre com o seu crescente acervo processual. Muito do que temos hoje em termos de jurisprudência defensiva e novas técnicas processuais decorreu de tentativas de fechar a Suprema Corte às demandas mais ordinárias. As súmulas - imaginadas e adotadas por inspiração do Ministro Victor Nunes Leal como compêndio da "jurisprudência predominante e firme" do STF e, depois, com a Emenda Constitucional n. ${ }^{\circ} 45 / 2004$, convertidas em "vinculantes" - são talvez o melhor exemplo.

Aliás, o STJ nasceu justamente como tentativa de resolver a "crise" que assolava e, a bem da verdade, ainda hoje assola - o STF. A ideia remonta à tese defendida, na década de 1960, por José Afonso da Silva, ${ }^{5}$ para quem, em síntese, a criação de um novo tribunal

\footnotetext{
${ }^{5}$ VELLOSO, Carlos Mário da Silva. O Superior Tribunal de Justiça - competências originária e recursal. In: TEIXEIRA, Sálvio de Figueiredo (coord.). Recursos no Superior Tribunal de Justiça. São Paulo: Saraiva, 1991, p. 9; MANCUSO, Rodolfo de Camargo. Recurso extraordinário e recurso especial. 12. ed. São Paulo: Revista dos Tribunais, 2013, p. 102.
} 
superior, o qual se encarregaria do direito objetivo federal, tiraria da competência do Supremo 60 ou $70 \%$ dos recursos, otimizando, assim, a atuação da Corte. ${ }^{6}$

Tanto no anteprojeto elaborado pela Comissão Afonso Arinos quanto no modelo ao final adotado pelo Constituinte de 1988, o STJ se destinava a ser o "guardião do direito federal comum no Estado federal brasileiro". ${ }^{7}$ Sua principal tarefa seria zelar pela "inteireza do sistema jurídico federal não-constitucional, assegurando-lhe validade e bem assim uniformidade de entendimento". Caber-lhe-ia, portanto, proferir, "dentro das questões federais legais, decisões paradigmáticas, que orientarão a jurisprudência do país e a compreensão do Direito federal". ${ }^{8}$ Mais do solucionar a lide, o recurso especial prestar-seia ao "controle da legalidade do julgado proferido pelo Tribunal a quo". 9

Entretanto, o discurso doutrinário a favor da nomofilaquia ficou distante da prática. A exemplo do que já acontecera no STF, mais do que simplesmente cassar a decisão recorrida que considerasse contrária à lei federal, o STJ, por expressa autorização constitucional (CF/1988, art. 105, III), deve proferir, ele próprio, nova decisão para a causa. O entendimento consolidado na Súmula n. ${ }^{\circ} 456$ do STF veio a prevalecer, com muita força, também no STJ. ${ }^{10}$ Há, a esse respeito, consenso doutrinário e jurisprudencial. E, não bastasse, a Emenda Regimental n. ${ }^{\circ}$ 24/2016 incluiu no Regimento Interno da Corte a previsão de que, conhecendo do especial, o STJ "julgará a causa, aplicando o direito à espécie" (RISTJ, art. 255, § 5. ${ }^{\circ}$ ), na linha do que já fizera o artigo 1.034, caput, do Código de Processo Civil de 2015.

Embora, na teoria, tenha o STJ a nobre função de preservar a ordem pública por meio da uniformização hermenêutica da lei federal, o recurso especial, na prática, quando bem manejado, dificilmente não será admitido, pois serão raras as “causas” que, quando decididas

\footnotetext{
${ }^{6}$ SILVA, José Afonso da. Do recurso extraordinário no direito processual brasileiro. São Paulo: Revista dos Tribunais, 1963, 436 e 455.

${ }^{7}$ VELLOSO, 1991, p. 11.

${ }^{8}$ ALVIM, Arruda. O antigo recurso extraordinário e o recurso especial (na Constituição Federal de 1988). In: TEIXEIRA, 1991, p. 155.

${ }^{9}$ RIBEIRO, Antônio de Pádua. Do recurso especial para o Superior Tribunal de Justiça. In: TEIXEIRA, 1991, p. 51.

${ }^{10}$ CARNEIRO, Athos Gusmão. Recurso especial, agravos e agravo interno. Rio de Janeiro: Forense, 2002, p. 69-71; GALVÃO, Ilmar Nascimento. Poder Judiciário. Reforma de 1988. O recurso especial no Superior Tribunal de justiça. In: TEIXEIRA, 1991, p. 89.
} 
pelos tribunais locais (TJs e TRFs) em "última ou única instância", não se enquadrarão em uma das alíneas do artigo 105, inciso III, da Constituição Federal.

Relembre-se, a propósito, que a palavra "causa", tal como empregada pelo texto constitucional, deve ser vista como sinônimo de processo ou ação, excetuando-se apenas alguns procedimentos de cunho administrativo, mas não os de jurisdição voluntária. ${ }^{11}$ Ademais, apesar de a Constituição exigir, para a admissibilidade do recurso especial, o prévio esgotamento das instâncias ordinárias, é indiferente se a ação se iniciou ou não perante o tribunal prolator da decisão contra a qual se pretenda interpor o recurso especial, o qual será admitido tanto nos processos que tramitam desde a primeira instância quanto nos processos de competência originária dos tribunais de segunda instância, se não cabível o recurso ordinário. ${ }^{12}$

Das hipóteses de admissibilidade contempladas pelo dispositivo constitucional aqui abordado, a mais ampla é a primeira (alínea "a"), sendo ela quase sempre invocada pelos mais diversos recorrentes. A prevalecer apenas o que textualmente estipula a Constituição Federal de 1988, praticamente toda questão federal decidida por tribunal local oportuniza o manejo do recurso especial sob o argumento de que houve contrariedade ou negativa de vigência à lei. $\mathrm{O}$ recurso especial, nesse contexto, serve muito mais à cassação da decisão que o recorrente reputa contrária aos seus interesses do que, como deveria ser, à fixação obrigatória de sentido ao ato normativo. ${ }^{13}$

Se, conceitualmente, contrariar e negar vigência são atos distintos, ${ }^{14}$ na prática, não há diferença. Desrespeitada ou ignorada a determinação de tratado ou lei federal, em tese, aceitar-se-á o apelo extremo. ${ }^{15}$

Aliás, para fins de admissibilidade do recurso especial, "tratado" é outra palavra usada em sua acepção mais lata, de modo a albergar, além dos tratados em sentido estrito, as demais formas de acordos internacionais. A nomenclatura é menos importante do que o conteúdo material, razão pela qual o recurso especial será admitido ante a contrariedade da

\footnotetext{
${ }^{11}$ LEAL, Fabio Resende. Recurso especial: teoria e prática. Curitiba: Juruá, 2020, p. 185; SARAIVA, José. Recurso especial e o STJ. São Paulo: Saraiva, 2002, p. 144-148; NEGRÃO, Perseu Gentil. Recurso especial: doutrina, jurisprudência, prática e legislação. São Paulo: Saraiva, 1997, p. 10; e RIBEIRO, 1991, p. 53.

${ }^{12}$ LEAL, 2020, p. 185.

${ }^{13}$ Idem, ibidem, p. 186.

${ }^{14}$ FORNACIARI JÚNIOR, Clito. Recurso especial com fundamento na letra "a" do permissivo constitucional. In: TEIXEIRA, 1991, p. 173-175.

${ }^{15}$ LEAL, 2020, p. 187.
} 
decisão recorrida com convenção, acordo, ajuste ou compromisso, desde que estes reflitam vontade normativa com repercussão na conduta tanto dos Estados celebrantes quanto na dos sujeitos internos à respectiva jurisdição. ${ }^{16}$

Ainda pensando na admissibilidade do recurso especial, a expressão "lei federal" é igualmente ampla, abarcando todo e qualquer ato normativo que, versando sobre os temas mencionados pelos artigos 22 e 24 da Constituição Federal (competência legislativa da União), tenha sido elaborado pelo Congresso Nacional e vigore por todo o território brasileiro. Nesse conceito de "lei federal", incluem-se as leis complementares, as leis ordinárias, as leis delegadas, as medidas provisórias, os decretos legislativos e as resoluções (CF/1988, art. 59, II a VII); a restrição é mínima. ${ }^{17}$ "Lei federal quer dizer direito federal. Tem-se, pois, como consequência lógica, que não cabe recurso especial com base [apenas] em direito local," como explica Carlos Mario da Silva Velloso. ${ }^{18}$

A alínea "b", por sua vez, procura garantir a autoridade do direito federal, estabelecendo a possibilidade de o Superior Tribunal de Justiça reformar a decisão que, contrariando o direito federal, considere válido ato de governo local. Cabe à corte superior restabelecer a autoridade do direito federal dando provimento ao recurso especial. Há, na espécie, um conflito entre o ato de governo local e a determinação da lei federal (“contencioso constitucional"), a ser solucionado, desde 1988, pelo STJ, e não mais pelo STF, como até então era. ${ }^{19}$

Também nessa hipótese de admissibilidade os recorrentes encontram conceitos amplos, pois os termos "ato" e "governo local" alcançam, de maneira generalizada, atos administrativos praticados por governador, prefeito, secretário estadual ou municipal, assembleia legislativa, câmara de vereadores etc. Quando houver, na lei federal, disposição contrária ao ato praticado localmente, há de prevalecer aquela em detrimento deste. ${ }^{20}$

Por fim, o recurso especial interposto sob o pálio da alínea "c" tem o dissenso jurisprudencial como sua base de sustentação. Será admitido o REsp quando dois tribunais diferentes (STJ, Súmula n. ${ }^{\circ}$ 13) tiverem, a partir de questões coincidentes ou assemelhadas,

\footnotetext{
16 SARAIVA, 2002, p. 179.

${ }^{17}$ LEAL, 2020, 187.

18 1991, p. 36.

${ }^{19}$ LEAL, 2020, p. 187-188.

${ }^{20}$ Idem, ibidem, p. 188
} 
interpretado de maneira distinta a mesma norma de direito federal, desde que a decisão a ser atacada não se alinhe à orientação que o STJ já tenha sobre o tema (atualidade da controvérsia $=$ STF, Súmula n. ${ }^{\circ} 286$, e STJ, Súmula n. ${ }^{\circ} 83$ ).

Dissecado nessas bases o artigo 105, inciso III, é quase impossível não concluir pela ampla admissibilidade do recurso especial. Como dito acima, dificilmente não se conseguirá enquadrar o processo no permissivo constitucional. Quase sempre ter-se-á decisão de "tribunal" que deu à "causa" solução que possa contrariar interpretação de "tratado" ou "lei federal". Também não será, no mais das vezes, difícil encontrar acórdãos com "interpretação divergente" a respeito da mesma questão.

Por isso, a amplitude de acesso concedida pela Carta Magna vem sendo combatida por alterações regimentais, imposições de técnicas processuais mais restritivas e, em especial, jurisprudência defensiva, da qual se extraem, como melhores exemplos, os seguintes enunciados, alguns já revogados ou superados pela evolução legislativa: necessidade de esgotamento da discussão perante as instâncias inferiores (STJ, Súmula n. ${ }^{\circ}$ 207; STF, Súmulas n. ${ }^{\text {os }} 281$ e 640); exigência de pré-questionamento das questões constitucional e federal (STJ, Súmula n. ${ }^{\circ} 211$; STF, Súmulas n. ${ }^{\text {os }} 282$ e 356); vedação de discussão afeita a matéria fática ou cláusula contratual (STJ, Súmulas n.$^{\circ} 5$ e 7 ; STF, Súmulas n. ${ }^{\text {os }} 279$ e 454); inexistência, no recurso especial, de questão constitucional capaz de manter a decisão recorrida (STJ, Súmula n. ${ }^{\circ}$ 126) ou inexistência, no recurso extraordinário, de ofensa a direito local (STF, Súmula n. ${ }^{\circ}$ 280); abrangência de todas as questões constantes da decisão recorrida, devendo o apelo atacar na íntegra os fundamentos adotados pelo órgão a quo (STF, Súmula n. ${ }^{\circ} 283$ ); necessidade de ratificação das razões recursais após publicação do acórdão proferido em embargos declaratórios posteriores (STJ, Súmula n. ${ }^{\circ}$ 418); inexistência de súmula ou entendimento jurisprudencial em sentido contrário ao defendido no recurso (STF, Súmula n. ${ }^{\circ}$ 286); e construção da fundamentação de modo a permitir a exata compreensão da controvérsia (STF, Súmula n. ${ }^{\circ} 284$ ).

Acontece que o resultado ainda está longe de ser satisfatório, como provam os números compilados no subitem anterior. Deixando de lado o problema da provável inconstitucionalidade de muitas dessas medidas restritivas (se a CF garante o amplo acesso, é duvidoso se poderia haver limitação em sede infraconstitucional, regimental e, pior ainda, jurisprudencial), é certo que, enquanto não se livrar de ter que julgar (qualquer) causa que 
se enquadre nas (amplas) hipóteses de admissibilidade do artigo 105, inciso III, o STJ continuará incapaz de bem executar a função nomofilácica para a qual foi criado e está vocacionado. A ruptura com tal quadro exige que se mude a Constituição.

\section{Propostas de alterações textuais na Constituição Federal}

\subsection{Reconfiguração do recurso especial}

Parece-me, em primeiro lugar, necessário constar expressamente da Constituição Federal a finalidade principal do recurso especial, que, antes de solucionar a lide (função recursal), deve servir para que o Superior Tribunal de Justiça resolva, em abstrato, questão de direito federal infraconstitucional (função nomofilácica). O recurso especial não pode, de modo algum, se prestar à mera revisão da justiça da decisão recorrida. A solução do conflito intersubjetivo de interesses, embora importante para recorrente e recorrido, deve ser tarefa secundária.

Além do mais, o recurso especial não pode ser visto apenas como arma contra o contencioso maciço. Mesmo que a questão posta nas razões recursais não se replique em múltiplos processos, ao menos em tese, deve ser possível o conhecimento do recurso especial. Mas deve estar destacada, no inciso III do artigo 105, a excepcionalidade do recurso especial. Não são todos nem muitos os especiais que merecem ser "selecionados" para serem julgados. Apenas os recursos cuja solução seja capaz de trazer impactos coletivos de ordem econômica, política, social e/ou jurídica é que se fazem merecedores de julgamento, sendo, pois, preciso que a Constituição assim preveja.

Isso, porém, não deverá transformar o recurso especial em mera ferramenta redutora do acervo processual do STJ. A diminuição do acervo, apesar de impreterível e imprescindível, há de ser, sim, buscada, mas como consequência positiva, e não, ela própria, como o principal objetivo, tal qual, equivocadamente, se quer com a Proposta de Emenda Constitucional n. ${ }^{\circ}$ 10/2017, a "PEC da relevância", desde fevereiro de 2019 parada aos cuidados de seu relator, Senador Rodrigo Pacheco, o recém eleito presidente do Senado Federal. 
Seguindo por essa linha de raciocínio, não concordo com as tentativas de se transformar o recurso especial em ação revisional, como pretende fazer a Proposta de Emenda Constitucional n. o 199/2019 (“PEC da prisão em segunda instância”). Há vários problemas aí. Cito alguns: (i) trocar o nome e a natureza jurídica não é garantia de que haverá a pretendida diminuição substancial do acervo processual; (ii) continuará sendo grande a recorribilidade interna vivenciada no STJ, uma vez que, contra decisões monocráticas e acórdãos proferidos na ação revisional, serão admitidos vários e sucessivos recursos, tal como hoje acontece nos recursos especiais; (iii) a fórmula adotada para o novo requisito de admissibilidade que se pretende impor (demonstração do "interesse geral das questões infraconstitucionais") se distancia muito da nossa experiência anterior (em especial, a arguição de relevância prevista pela EC n. ${ }^{\circ}$ 1/1969 e a repercussão geral trazida pela EC n. ${ }^{\circ}$ 45/2004 e hoje regulada pelo art. 1.035 do CPC/2015) e é também demasiadamente aberta, podendo, em tese, permitir que qualquer questão infraconstitucional venha a ser enfrentada pelo STJ, corte à qual, no entanto, deve caber o trato apenas das questões federais infraconstitucionais, relevantes e transcendentes; (iv) exigir unanimidade para o conhecimento da ação revisional especial, como consta da PEC, irá, na prática, inviabilizar o acesso ao STJ por meio do novo instrumento processual, o que provocará o uso de outros expedientes (mandado de segurança e habeas corpus, p. ex.) e, por conseguinte, impedirá o almejado decréscimo no número de processos; (v) é duvidoso se essa nova ação permitirá ao STJ exercer a função nomofilácica e, com isso, impor sua autoridade hermenêutica, dando, dentro do processo, a última palavra sobre a interpretação das leis federais; (vi) além de caracterizar grande ruptura histórica, a proposta de alteração constitucional, por si só, não garante que as penas sejam cumpridas em prazos mais exíguos (o grande objetivo perseguido pela PEC), pois nada impedirá que o STJ receba a ação revisional com efeito suspensivo (tutela provisória $=\mathrm{CPC} / 2015$, art. 294 e ss.), como hoje pode acontecer com as ações rescisórias (CPC/2015, art. 969, in fine) e revisões criminais; (vii) a PEC desconsidera que o recurso especial desempenha a importantíssima tarefa de uniformização jurisprudencial a respeito da interpretação e aplicação das leis federais, dissipando a divergência de entendimento que pode existir entre os vários tribunais locais (CF/1988, art. 105, III, “c”), o que permitirá que um acórdão local transite em julgado dando à mesma questão solução diferente da adotada por outro tribunal de segunda instância ou contrária ao entendimento 
do STJ; (viii) também despreza o fato de que o recurso é utilizado nos processos em que se discute temas não criminais e, como é o Poder Público quem mais se vale do REsp para postergar as obrigações que lhe são impostas por condenações judiciais, permitir o imediato trânsito em julgado das decisões de segunda instância trará enorme reflexo orçamentário, problema que, provavelmente, será igualmente sentido pelos particulares; (ix) se houver o trânsito em julgado ainda perante os tribunais locais, a execução civil será definitiva e não haverá como se exigir a contracautela, cenário no qual o exequente expropriará em definitivo o executado e, provavelmente, de quase nada adiantará o êxito colhido futuramente na ação revisional julgada pelo $\mathrm{STJ}$; $(x)$ no Congresso, nada se fala a respeito da imprescindível complementação normativa a ser feita em sede infraconstitucional $\left(\mathrm{CPC} / 2015\right.$, Lei n. ${ }^{\circ}$ 8.038/1990 e RISTJ) ou sobre eventuais mudanças no recurso de revista; (xi) a PEC, quando aprovada, deverá entrar imediatamente em vigor (art. 3. ${ }^{\circ}$ ), mas não prevê prazo para a propositura das "ações revisionais" e, por conta desse vácuo normativo, é possível defender que as novas ações poderão ser propostas a qualquer tempo, possibilidade que trará, apesar do trânsito em julgado formalizado após o pronunciamento de segunda instância, muita instabilidade e insegurança (a questão a ser revista e, consequentemente, a lide permanecerão em aberto, a despeito do trânsito em julgado).

É melhor, portanto, que o especial continue sendo recurso. Ademais, deve ser mantida no texto constitucional a expressão "julgar, em recurso especial, as causas decididas", em respeito à história do processo brasileiro e para que, de fato, possa haver, no STJ, um novo julgamento da causa (função recursal), antes do qual, contudo, sempre deverá existir a preocupação com a definição de sentido, enquanto norma jurídica de obrigatória observância, do direito federal infraconstitucional (função nomofilácica). Selecionado o especial, a Corte, antes, resolve a questão, fixando, em abstrato, uma tese jurídica de obrigatória observância nos casos análogos, e, depois, usa essa mesma tese para rever, no próprio processo, o que deliberado nas instâncias ordinárias.

Não deve haver, inclusive na Constituição, nenhuma diferença entre recurso especial repetitivo e recurso especial não repetitivo no que se refere à vinculação das instâncias ordinárias e da Administração Pública aos veredictos da corte de vértice. Definida a questão em recurso especial, a tese nessa ocasião fixada há de ser vinculante, esteja ou não, no momento, caracterizada a repetitividade de feitos. 
Enfim, para que tudo isso seja possível, ao invés do que propõem as Propostas de Emenda Constitucional n. ${ }^{\circ}$ 10/2017 e 199/2019, o inciso III do artigo 105 da Constituição Federal deve passar a vigorar com a seguinte redação:

visando solucionar questão de direito federal infraconstitucional, mesmo que não haja multiplicidade de processos, selecionar e julgar, em recurso especial, as causas decididas, em única ou última instância, pelos Tribunais Regionais Federais ou pelos tribunais dos Estados, do Distrito Federal e Territórios, quando a decisão recorrida: [...].

\subsection{Relevância e transcendência da questão federal}

É, no entanto, importante constar do texto constitucional expressa limitação à admissibilidade do recurso especial. Primeiro, para se reforçar a função nomofilácica ínsita a esse tipo de técnica processual e, segundo, a fim de se permitir a seleção coerente e responsável dos apelos cujo julgamento possa realmente trazer impactos ao patrimônio jurídico nacional, e não apenas satisfação a recorrente ou recorrido.

A meu juízo, ao invés de repetirmos a expressão "repercussão geral" ou adotarmos a demonstração do "interesse geral das questões infraconstitucionais", fórmula trazida pela PEC n. ${ }^{\circ}$ 199/2019, devemos reintroduzir em nosso ordenamento jurídico a "relevância da questão federal", (formalmente) um novo e rigoroso requisito de admissibilidade do recurso especial (juízo preliminar de admissibilidade) e (materialmente) pressuposto indicativo da importância e transindividualidade da questão federal nele versada.

Em respeito à autoridade do STJ e para se manter o sistema íntegro e coerente, via de regra, as questões federais precedentemente solucionadas não serão revisitadas pela Corte (efeito vinculante da ratio decidendi do leading case $=$ stare decisis), a qual somente poderá reanalisar e superar seus precedentes em situações excepcionais, de modo que, nos assuntos não inéditos, o Tribunal só atuará se houver significativa razão para o overruling.

Lembre-se, nesse passo, que o sistema atual, pelo que preveem o artigo 1.030, inciso I, alínea "b", do Código de Processo Civil de 2015 (obrigatória negativa de seguimento a REsp interposto contra acórdão em conformidade com o entendimento exarado pelo STJ em julgamento anterior de repetitivo) e os artigos 256-S a 256-X do Regimento Interno do Superior Tribunal de Justiça (procedimento a ser observado para a revisão de tese jurídica fixada em repetitivo), impõe a negativa de seguimento ao recurso especial interposto contra 
acórdão que esteja em conformidade com o entendimento exarado anteriormente pelo STJ no regime de julgamento dos repetitivos e só permite revisão das teses por iniciativa do próprio Tribunal ou do MPF. Reputo, por isso, necessário termos a excepcional, mas expressa autorização constitucional para a superação do precedente vinculante mediante provocação do próprio jurisdicionado, ferramenta esta indispensável à evolução do direito e, por conseguinte, à legitimidade do sistema precedentalista.

Nos assuntos inéditos, como antes posto, a atuação do STJ depende da demonstração da relevância econômica, política social e/ou jurídica, à qual há de se somar, ainda, a transcendência, assim entendida, repete-se, a questão que, além de relevante, interessará não apenas às partes, mas à coletividade como um todo depois de resolvida, seja porque a solução da questão é capaz de repercutir no patrimônio jurídico do país, seja porque a questão é ou pode vir a ser discutida em um número grande de processos.

Estou, aqui, a sugerir que adotemos para a "relevância da questão federal" o que a melhor doutrina pensa a respeito da repercussão geral. ${ }^{21}$ Assim, merecerá conhecimento o recurso especial cujas razões versem sobre questão federal que seja, ao mesmo tempo, relevante e transcendente.

Devemos também adotar para a relevância da questão federal fórmula parecida com a hoje esculpida no artigo 1.035, parágrafo $1 .^{\circ}$, do Código de Processo Civil de 2015. E, então, poderemos entender como relevantes os temas que interessem à sociedade como um todo (relevância social); que sejam concernentes à organização do Estado e sua relação com os particulares, bem como às demandas envolvendo a distribuição e o exercício do poder estatal (relevância política); e que possam repercutir substancial e decisivamente no orçamento público ou de famílias e empresas privadas (relevância econômica). ${ }^{22}$

Juridicamente, sempre que houver necessidade de se dotar o direito federal infraconstitucional de coerência e previsibilidade através da atuação do STJ no exercício de sua função nomofilácica ou quando se fizer necessária a fixação de uma interpretação única e final a respeito do direito federal infraconstitucional, haverá a proeminência capaz de autorizar o conhecimento do recurso especial (relevância jurídica). Terão, destarte,

\footnotetext{
${ }^{21}$ MARINONI, Luiz Guilherme; MITIDIERO, Daniel. Repercussão geral no recurso extraordinário. São Paulo: Revista dos Tribunais, 2007, p. 31-37.

${ }^{22}$ LEAL, 2020, p. 223-224.
} 
relevância jurídica as questões de direito federal infraconstitucional que tragam em si múltiplas possibilidades hermenêuticas (complexidade) e as ainda não decididas pelo STJ (ineditismo). ${ }^{23}$

Penso que o conceito jurídico-processual de relevância há de ser indeterminado, fluído, aberto, de modo a exprimir a ideia de saliência e importância, bem como permitir a seleção (criteriosa) dos recursos a serem julgados pelo Superior Tribunal de Justiça. Será, pois, em tese, relevante a questão relacionada a assunto de grande valor ou interesse, não necessariamente pecuniário, cuja solução seja essencial ou impostergável. ${ }^{24}$

Necessário, ainda, se encravar no conceito de "relevância da questão federal" também a transcendência. Se a questão posta no recurso especial, a despeito de relevante, interessar apenas às partes, inexistirá justificativa para a intervenção do STJ, bastando, para a resolução do processo, a manifestação das instâncias ordinárias. Qualitativamente, a matéria posta no recurso especial deve repercutir para além dos estreitos limites definidos pelo conflito intersubjetivo de interesses que afasta o recorrente do recorrido. É transcendente a questão cuja solução venha a repercutir no patrimônio jurídico nacional, por estabelecer aquela que, das várias possibilidades interpretativas possíveis, dali por diante, servirá de paradigma a ser obrigatoriamente adotado na solução das contendas análogas. Quantitativamente, a transcendência se caracteriza pela multiplicidade de processos no momento (transcendência presente) ou, dada a probabilidade de multiplicação, no futuro (transcendência potencial). ${ }^{25}$

É preciso, ademais, que se garanta a admissibilidade de ao menos um recurso especial que trate de questão federal repetidamente discutida em múltiplos processos, sendo, nesse caso, presumida a relevância da questão federal. Da mesma forma, comprovada divergência de posicionamento acerca da interpretação do direito federal infraconstitucional, presumirse-á a relevância para fins de conhecimento do recurso especial, proposta que se justifica no fato de que, havendo a multiplicidade de processos, não há como se ter por irrelevante a questão federal posta nos recursos especiais repetitivos, um dos quais devendo, por conseguinte, ser escolhido como forma de solucionar interpretativamente o assunto. ${ }^{26}$

\footnotetext{
${ }^{23}$ Idem, ibidem, p. 224.

${ }^{24}$ Idem, ibidem, p. 223.

${ }^{25}$ Idem, ibidem, p. 225.

${ }^{26}$ Idem, ibidem, p. 223.
} 
A princípio, será do recorrente o ônus de demonstrar, ainda que minimamente, a proeminência e importância do tema posto no apelo excepcional, ${ }^{27}$ o qual só deve ser recusado, sob a ótica da relevância da questão federal, se, ao menos, 3/5 dos ministros integrantes do órgão encarregado de julgar o recurso no mérito (pelas regras atuais, Corte Especial ou Seção no caso dos repetitivos e Turma no caso dos não repetitivos) se manifestarem contra a presença do requisito de admissibilidade. Justifica a proposta de um quórum de 3/5 o número de ministros que integram os órgãos colegiados do STJ, todos múltiplos de cinco $\left(15,10\right.$ e 5 , respectivamente) ${ }^{28}$

Deve, pois, ser renomeado como parágrafo $4 .^{\circ}$ o atual parágrafo único do artigo 105 , ao qual devem ser acrescentados, como parágrafos $1 .^{\circ}$ e $2 .^{\circ}$, dispositivos com as seguintes redações:

$\S 1 .^{\circ} \mathrm{O}$ Superior Tribunal de Justiça não conhecerá do recurso especial, pela manifestação de três quintos dos membros do órgão competente para o julgamento, quando a questão federal nele versada tiver sido objeto de anterior análise e não houver justificativa para a superação da tese precedentemente fixada ou, em se tratando de tema inédito, não apresentar relevância do ponto de vista econômico, político, social ou jurídico que ultrapasse os interesses subjetivos do processo.

$\S 2$. $^{\circ}$ Presumir-se-á a existência de relevância da questão federal, para fins de admissibilidade do recurso especial, quando houver multiplicidade de processos ou comprovada divergência de posicionamento acerca da interpretação do direito federal infraconstitucional.

\subsection{Efeito vinculante}

Em complementação, a atribuição de efeito vinculante ao julgamento do recurso especial deve contar com previsão constitucional expressa, pois, graças a ela, haverá redistribuição de poder e, por conseguinte, subjugação das autoridades judiciárias de menor escalão, bem como dos administradores públicos, todos estes obrigados a se sujeitarem aos precedentes do Superior Tribunal de Justiça. Essa, a única forma de se legitimar, sob a ótica da distribuição do poder estatal e reorganização do sistema de freios e contrapesos, a submissão dos demais órgãos judiciais e dos administradores públicos aos precedentes da corte de sobreposição.

${ }^{27}$ Idem, ibidem, p. 225.

${ }^{28}$ Idem, ibidem, p. 226-227. 
Ademais, parece-me importante a ressalva, também expressa na Carta Magna, de que a vinculação não se dará ao precedente propriamente dito, mas à sua ratio decidendi ou tese jurídica, isto é, a fundamentação determinante do veredicto, esta, sim, a ser posteriormente observada pelos demais órgãos do Poder Judiciário e pela Administração Pública direta e indireta, nas esferas federal, estadual e municipal.

Reputo, por tais razões, necessário acrescer ainda ao artigo 105 outro parágrafo, a ser assim redigido:

$\S 3 .^{\circ}$ Ao final do julgamento do recurso especial, o Superior Tribunal de Justiça firmará tese jurídica acerca da questão federal resolvida, a ser posteriormente observada pelos demais órgãos do Poder Judiciário e pela Administração Pública direta e indireta, nas esferas federal, estadual e municipal.

\subsection{Reclamação}

Em termos de vinculação, o precedente cunhado no STJ por meio do recurso especial deve ser o mais forte possível, o que significa, na linha do que prega boa parte da doutrina pátria, ${ }^{29}$ permitir o uso de reclamação contra o seu descumprimento. Ora, a mera previsão do efeito vinculante é insuficiente. A Constituição deve autorizar reclamação ao STJ caso haja inobservância da tese jurídica firmada em recurso especial.

Essa alteração constitucional se faz ainda mais importante na medida em que, recentemente, a despeito da literal disposição do artigo 988, parágrafo $1 .^{\circ}$, do Código de Processo Civil de 2015 (competência para julgar a reclamação que é do órgão cuja autoridade decisória se pretende preservar), a Corte Especial do STJ considerou que não caberia ao tribunal superior apreciar reclamações contra descumprimento das teses jurídicas estabelecidas em recurso especial repetitivo. Prevaleceu, para tanto, a ideia, expressada no voto da Relatora, Ministra Nancy Andrighi, de que a reclamação seria incabível para o controle da aplicação, pelos tribunais inferiores, de tese jurídica fixada em julgamento de recursos especiais repetitivos, controle este que, sob a égide do vigente CPC, deveria ser feito pelo sistema recursal e, excepcionalmente, por meio da ação rescisória. ${ }^{30}$

\footnotetext{
${ }^{29}$ ALVIM, Teresa Arruda. Modulação na alteração da jurisprudência firme ou de precedentes vinculantes. São Paulo: Revista dos Tribunais, 2019, p. 95-101.

${ }^{30}$ BRASIL. Superior Tribunal de Justiça (Corte Especial). Reclamação n. ${ }^{\circ}$ 36.476/SP. Relatora: Ministra Nancy Andrighi. Brasília, DF, 5 de fevereiro de 2020. DJe 06/03/2020.
} 
É possível compreender as razões que levaram a esse veredicto: a admissão irrestrita de reclamações certamente causaria aumento no número de processos a serem analisados no STJ, o que, além de indesejável, seria contrário aos propósitos que justificaram as modificações trazidas pela Lei $n .^{\circ} 13.256 / 2016$ ainda durante a vacatio legis da Lei n. $^{\circ}$ 13.105/2015. No entanto, convém lembrar que a opção brasileira por um sistema precedentalista exige que se respeite o que antes foi decidido (stare decisis $=\mathrm{CPC} / 2015$, arts. 926 e 927) e, nesse contexto, é de grande importância a reclamação como técnica processual capaz de fazer com que os pronunciamentos vinculantes das cortes de vértice sejam, de fato, observados pelos tribunais locais e juízos de piso.

Via de regra, não se pode desconsiderar as manifestações antecedentes do STJ e, assim sendo, as questões já decididas, mesmo se relevantes, não serão reavaliadas pelo Tribunal. A revisitação de questão sobre a qual já há precedente deve ser extraordinária, isto é, acontecerá apenas quando houver justificativa para a superação da tese precedentemente fixada (perda de correspondência do precedente aos padrões de congruência social ou de consistência sistêmica). ${ }^{31}$ Ainda mais excepcionalmente, pode ser cabível a revisão posterior da tese jurídica caso se constate sua incompatibilidade com a ratio decidendi do precedente que lhe deu origem ou inadequação entre a tese fixada e a lei interpretada. Porém, só conseguiremos esse nível de obediência se instituirmos a reclamação contra o descumprimento das teses jurídicas fixadas em recurso especial, tal como fizemos, em 2004, para as hipóteses de aplicação indevida ou contrariedade a súmula vinculante (CF, art. 103A, § 3. ${ }^{\circ}$, incluído pela EC n. $\left.{ }^{\circ} 45 / 2004\right)$.

É evidente que a reclamação não pode ser usada como sucedâneo recursal. Seu cabimento deve ser excepcional e limitado às situações nas quais não se aplicou a ratio do precedente vinculante sem que houvesse justificativa para tanto (distinguishing ou overruling) e - o mais importante - desde que tenha havido o esgotamento da discussão acerca da aplicabilidade/inaplicabilidade nas instâncias ordinárias (CPC/2015, art. 988, § $5^{\circ}$ ). Permitir que dado tribunal local desaplique a tese do STJ enquanto seus congêneres estão a aplicá-la em casos análogos significaria desprestigiar a isonomia e a segurança jurídica, justamente os principais valores que se pretende proteger com a adoção de um

\footnotetext{
${ }^{31}$ MARINONI, Luiz Guilherme. Precedentes obrigatórios. 5. ed. São Paulo: Revista dos Tribunais, 2016, p.
} 271. 
sistema precedentalista. Sendo tarefa do STJ zelar pela uniformidade na aplicação do direito federal objetivo, que, sendo único, não admite interpretações antagônicas, é da corte superior a competência para zelar pela replicação de seus precedentes vinculantes. Em outras palavras: é do STJ a competência para impor obediência às suas teses por meio do julgamento da reclamação (CPC/2015, art. 988, IV e $\left.§ 1 .^{\circ}\right)$.

A par disso, prever na Constituição o cabimento da reclamação e a competência originária do STJ para julgá-la significa privilegiar e destacar a estrutura piramidal e hierarquizada de nosso sistema de justiça, dentro do qual, em prol da isonomia e segurança jurídica, os tribunais locais e juízos de piso são obrigados a se curvar aos pronunciamentos do tribunal de vértice no que se refere a questões envolvendo direito infraconstitucional federal. Decidido o tema no STJ, decidido está o tema. Ao atribuir sentido ao texto legal, o STJ, na verdade, deu parâmetros finais à norma jurídica, que, então, deve ser obedecida. Subjugados pela autoridade hierárquica do tribunal de sobreposição, nenhum desembargador ou juiz poderá julgar de forma distinta. ${ }^{32}$

A adoção da reclamação inicialmente pode mesmo provocar um incremento no número de processos endereçados ao STJ. Isso, todavia, não deve prejudicar, no médio prazo, o bom andamento dos feitos na Corte, pois, junto com a instituição da reclamação, deverá ser - como visto anteriormente - estabelecida a relevância da questão federal como rigorosíssimo filtro de admissibilidade dos recursos especiais, fato que provocará substancial diminuição no acervo de processos. Sobrará, assim, tempo e estrutura suficiente para dar vazão às reclamações.

Com o passar do tempo, sendo cassados os acórdãos contrários às teses precedentemente estipuladas, "serão cada vez menos os casos a ensejar reclamação e, talvez, cheguemos ao estágio ideal no qual os pronunciamentos do STJ sejam espontaneamente adotados pelos juízos inferiores e administradores públicos". ${ }^{33}$

Considero, pois, imperativo, para que as alterações anteriormente sugeridas não fiquem inócuas, alterar-se a redação da alínea “f” do inciso I do artigo 105, a qual há de ficar de tal modo redigida: "f) a reclamação para a preservação de sua competência, garantia da autoridade de suas decisões e observância da tese jurídica firmada em recurso especial.”

\footnotetext{
${ }^{32}$ LEAL, 2020, p. 271.
}

${ }^{33}$ Idem, ibidem, p. 254. 


\section{Conclusão}

Os dados estatísticos apresentados no subitem 2 levam à constatação de que o sistema atual, no tocante ao acesso por meio do recurso especial ao Superior Tribunal de Justiça, está à beira do colapso. Por mais que se faça nas secretarias e gabinetes, o trabalho é enorme e, consequentemente, interminável. Nenhum ministro, mesmo dispondo de modernas ferramentas tecnológicas e vários assessores, consegue dar vazão às centenas de processos que chegam a cada mês. Julga-se muito, mas, em razão do acervo gigantesco, acaba-se por também julgar mal. E as medidas já implementadas no intuito de resolver o problema (restrições legais e regimentais, súmulas e jurisprudência defensiva) se mostraram incapazes de sequer amenizá-lo.

Urge, portanto, que se limite ainda mais o uso do recurso especial; é preciso instituir o quanto antes, por alteração constitucional literal, a relevância da questão federal como requisito de admissibilidade do recurso especial, o qual, a partir daí, deve ser visto e usado como técnica processual verdadeiramente excepcional, capaz de gerar teses paradigmáticas e vinculantes.

Tal modificação é necessária, pois, como visto no subitem 3, apesar da retórica doutrinária, a Constituição Federal, em sua redação atual, concede, sim, amplo acesso ao STJ por meio do recurso especial. A rigor, pelo que se depreende do texto constitucional, a Corte não tem verdadeira vocação precedentalista. Não lhe foi dada, pelo constituinte originário, a função de criar teses abstratas. A tão propalada função nomofilácica está ausente na Carta Magna. Conforme literalmente previsto no inciso III do artigo 105, cabe ao STJ rever, em grau de recuso especial, as causas decididas pelos tribunais. Hoje, a formação de teses abstratas, quando muito, é tarefa secundária e quase que restrita apenas aos recursos repetitivos.

Todavia, é imprescindível e inadiável mudar tal cenário. Deve o STJ ser transmutado em uma verdadeira corte de precedentes e teses vinculantes. Quando ali aportar, o processo deve ser primordialmente objetivo. A solução da lide há de ser tida como a empreitada subsidiária a ser desenvolvida pelos ministros, cujo trabalho principal, sendo ou não repetitivo o recurso especial, deve ser a solução, em abstrato, apenas e tão somente de 
questão federal proeminente, por meio da fixação de tese jurídica de obrigatória observância posterior nos casos análogos.

Proponho, a partir dessas premissas, que a Constituição Federal seja modificada nos seguintes pontos: (i) alteração na redação do inciso III do artigo 105, para se reconfigurar o recurso especial e, com isso, legitimar constitucionalmente a objetivação desta técnica processual; (ii) renumeração do atual parágrafo único do artigo 105 como parágrafo 4. ${ }^{\circ}$; (iii) acréscimo de um novo parágrafo $\left(\S 1^{\circ}{ }^{\circ}\right)$, instituindo a relevância (econômica, política, social e/ou jurídica) e/a transcendência (qualitativa e/ou quantitativa, presente ou potencial) da questão federal sub judice, como requisito de admissibilidade do recurso especial e, mais ainda, como forma de não se permitir, via de regra, a ordinária revisão dos temas anteriormente decididos pelo STJ; (iv) inclusão de outro parágrafo $\left(\S 2 .^{\circ}\right)$, do qual deve constar a presunção de relevância quando houver multiplicidade de processos ou comprovada divergência de entendimentos; $(v)$ adição de mais um parágrafo $\left(\S 3 .^{\circ}\right)$, este enunciando caber ao STJ, no julgamento dos recursos especiais, não necessariamente repetitivos, fixar tese jurídica, abstrata e dotada de efeito vinculante, acerca da questão federal então resolvida; e, por fim, (vi) modificação da alínea "ff" do inciso I do artigo 105, para tornar inequívoca a possibilidade de reclamação contra a inobservância da tese fixada em recurso especial.

\section{REFERÊNCIAS}

ALBUQUERQUE, Leonidas Cabral. Admissibilidade do recurso especial. Porto Alegre: Sergio Antonio Fabris, 1996.

ALVIM, Arruda. A argüição de relevância no recurso extraordinário. São Paulo: Revista dos Tribunais, 1988.

ALVIM, Arruda. O antigo recurso extraordinário e o recurso especial (na Constituição Federal de 1988). In: TEIXEIRA, Sálvio de Figueiredo (coord.). Recursos no Superior Tribunal de Justiça. São Paulo: Saraiva, 1991.

ALVIM, Teresa Arruda. Modulação na alteração da jurisprudência firme ou de precedentes vinculantes. São Paulo: Revista dos Tribunais, 2019. 
BATISTA, N. Doreste. Da argüição de relevância no recurso extraordinário. Rio de Janeiro: Forense, 1978.

BENETI, Sidnei. Memórias theotônicas. Revista do Advogado, São Paulo, n. 136, p. 13-25, dez. 2017.

BRASIL. Superior Tribunal de Justiça (Corte Especial). Reclamação n. ${ }^{\circ}$ 36.476/SP. Relatora: Ministra Nancy Andrighi. Brasília, DF, 5 de fevereiro de 2020. DJe 06/03/2020.

BRASIL. Regimento Interno do Superior Tribunal de Justiça. Atualizado até a Emenda Regimental n. ${ }^{\circ}$ 30, de 22 de maio de 2018. Disponível em: https://ww2.stj.jus.br/publicacaoinstitucional/index.php/Regimento/issue/view/1/sho wToc. Acesso em: 11 jul. 2018.

BRASIL. Câmara dos Deputados. Proposta de Emenda Constitucional n. ${ }^{\circ}$ 209/2012. Disponível em: https://www.camara.leg.br/proposicoesWeb/fichadetramitacao?idProposicao=55394 7. Acesso em: 1 fev. 2019.

BRASIL. Câmara dos Deputados. Proposta de Emenda Constitucional n. ${ }^{\circ}$ 199/2019. Disponível em: https://www.camara.leg.br/proposicoesWeb/fichadetramitacao?idProposicao=22299 38. Acesso em: 05 dez. 2019.

BRASIL. Senado Federal. Proposta de Emenda Constitucional n. ${ }^{o}$ 10/2017. Disponível em: https://www25.senado.leg.br/web/atividade/materias/-/materia/128403. Acesso em: 5 dez. 2019.

BUNDESAMT FÜR JUSTIZ. Zivilprozessordnung. Disponível em: https://www.gesetzeim-internet.de/zpo/index.html. Acesso em: 6 fev. 2019.

BURNHAM, William. Introduction to the law and legal system of the United States. 2.nd ed. Saint Paul: West Publishing, 1999.

BUSTAMANTE, Thomas da Rosa de. Teoria do precedente judicial: a justificação e a aplicação das normas jurisprudenciais. São Paulo: Noeses, 2012.

CALAMANDREI, Piero. La cassazione civile: storia e legislazione. Napoli: Morano, 1919, t. 1 . 
CARNEIRO, Athos Gusmão. Recurso especial, agravos e agravo interno. Rio de Janeiro: Forense, 2002.

DANTAS, Marcelo Navarro Ribeiro. Reclamação constitucional no direito brasileiro. Porto Alegre: Sergio Antonio Fabris, 2000.

FONTOURA, Lucia Helena Ferreira Palmeiro da. Recurso especial: questão de fato/questão de direito. Porto Alegre: Sergio Antonio Fabris, 1993.

FORNACIARI JÚNIOR, Clito. Recurso especial com fundamento na letra "a" do permissivo constitucional. In: TEIXEIRA, Sálvio de Figueiredo (coord.). Recursos no Superior Tribunal de Justiça. São Paulo: Saraiva, 1991.

GALVÃO, Ilmar Nascimento. Poder Judiciário. Reforma de 1988. O recurso especial no Superior Tribunal de justiça. In: TEIXEIRA, Sálvio de Figueiredo (coord.). Recursos no Superior Tribunal de Justiça. São Paulo: Saraiva, 1991.

GARNER, Bryan A. Black's Law Dictionary. Dallas: West Publishing, 1996.

HOLLIDAY, Gustavo Calmon. A reclamação constitucional no novo CPC. Belo Horizonte: Fórum, 2016.

KELSEN, Hans. Teoria pura do direito. Tradução de João Baptista Machado. Coimbra: Armênio Amado, 1984.

LEAL, Fabio Resende. Recurso especial: teoria e prática. Curitiba: Juruá, 2020.

LEAL, Victor Nunes. Passado e futuro da súmula do STF. Revista de Direito Administrativo, Rio de Janeiro, v. 145, p. 1-20, jan. 1981. Disponível em: http://bibliotecadigital.fgv.br/ojs/index.php/rda/article/view/43387. Acesso em: 03 jul. 2018.

MANCUSO, Rodolfo de Camargo. Recurso extraordinário e recurso especial. 12. ed. São Paulo: Revista dos Tribunais, 2013.

MARINONI, Luiz Guilherme; MITIDIERO, Daniel. Repercussão geral no recurso extraordinário. São Paulo: Revista dos Tribunais, 2007.

MARINONI, Luiz Guilherme. O STJ enquanto corte de precedentes: recompreensão do sistema processual da corte suprema. 2. ed. São Paulo: Revista dos Tribunais, 2014.

MARINONI, Luiz Guilherme. O julgamento nas cortes supremas: precedentes e decisão do recurso diante do novo CPC. São Paulo: Revista dos Tribunais, 2015. 
MARINONI, Luiz Guilherme. Precedentes obrigatórios. 5. ed. São Paulo: Revista dos Tribunais, 2016.

MITIDIERO, Daniel. Cortes superiores e cortes supremas. São Paulo: Revista dos Tribunais, 2013.

MITIDIERO, Daniel. Precedentes: da persuasão à vinculação. 2. ed. São Paulo: Revista dos Tribunais, 2017.

NEGRÃO, Perseu Gentil. Recurso especial: doutrina, jurisprudência, prática e legislação. São Paulo: Saraiva, 1997.

NERY JUNIOR, Nelson; ABBOUD, Georges. Recursos para os tribunais superiores e a Lei 13.256/2016. Revista de Processo, São Paulo, v. 41, n. 257, p. 217-235, jul. 2016.

PANTUZZO, Giovanni Mansur Solha. Prática dos recursos especial e extraordinário. Belo Horizonte: Del Rey, 1998.

PINTO, Nelson Luiz. Recurso especial para o Superior Tribunal de Justiça. São Paulo: Malheiros, 1992.

REVISTA DO ADVOGADO. 20 anos do Superior Tribunal de Justiça. São Paulo: AASP, ano 29, n. 103, maio 2009. ISSN 0101-7497.

REVISTA DO ADVOGADO. 30 anos do Superior Tribunal de Justiça. São Paulo: AASP, ano 39, n. 141, abr. 2019. ISSN 0101-7497.

RIBEIRO, Antônio de Pádua. Do recurso especial para o Superior Tribunal de Justiça. In: TEIXEIRA, Sálvio de Figueiredo (coord.). Recursos no Superior Tribunal de Justiça. São Paulo: Saraiva, 1991.

SANSEVERINO, Paulo de Tarso. Recursos repetitivos no STJ. In: III CONGRESSO DE ATUALIZAÇÃO E APERFEIÇOAMENTO JURÍDICO. Bauru: Ordem dos Advogados do Brasil, Subseção de Bauru, 2018.

SARAIVA, José. Recurso especial e o STJ. São Paulo: Saraiva, 2002.

SILVA, José Afonso da. Do recurso extraordinário no direito processual brasileiro. São Paulo: Revista dos Tribunais, 1963.

SOUZA, Marcelo Alves Dias de. Do precedente judicial à súmula vinculante. Curitiba: Juruá, 2008.

STRECK, Lenio Luiz; ABBOUD, Georges. O que é isto: o precedente judicial e as súmulas vinculantes. 3. ed. Porto Alegre: Livraria do Advogado, 2015. 
Revista Eletrônica de Direito Processual - REDP.

Rio de Janeiro. Ano 15. Volume 22. Número 3. Setembro a Dezembro de 2021

Periódico Quadrimestral da Pós-Graduação Stricto Sensu em Direito Processual da UERJ

Patrono: José Carlos Barbosa Moreira (in mem.). ISSN 1982-7636. pp. 288-314

www.redp.uerj.br

Superior Tribunal de Justiça. Relatório Estatístico

2017.

Disponível

em:

http://www.stj.jus.br/webstj/Processo/Boletim/verpagina.asp?vPag=0\&vSeq=301.

Acesso em: 8 nov. 2018.

Superior

Tribunal

de

Justiça.

Relatório

Estatístico

2018.

Disponível

em:

http://www.stj.jus.br/webstj/Processo/Boletim/verpagina.asp?vPag=0\&vSeq=327.

Acesso em: 29 abr. 2019.

Superior

Tribunal

de

Justiça.

Relatório

Estatístico

2019.

Disponível

em:

http://www.stj.jus.br/webstj/Processo/Boletim/verpagina.asp?vPag=0\&vSeq=343.

Acesso em: 30 jan. 2020.

VELLOSO, Carlos Mário da Silva. O Superior Tribunal de Justiça - competências originária

e recursal. In: TEIXEIRA, Sálvio de Figueiredo (coord.). Recursos no Superior Tribunal de Justiça. São Paulo: Saraiva, 1991.

WAMBIER, Teresa Arruda Alvim (coord). Aspectos polêmicos e atuais do recurso especial e do recurso extraordinário. São Paulo: Revista dos Tribunais, 1997.

ZANETI JÚNIOR, Hermes. O valor vinculante dos precedentes: teoria dos precedentes normativos formalmente vinculantes. 3. ed. Salvador: Jus Podivm, 2017. 